\title{
Nöral migrasyon defektini saptamada ultrasonografi ve manyetik rezonans görüntülemenin kullanımı
}

\author{
Using of magnetic resonance imaging and ultrasonography in neural migration \\ defect detection
}

Ayhan Atıgan, Mehmet Babür Kaleli

Gönderilme tarihi:17.03.2018

Kabul tarihi:09.11.2018

\begin{abstract}
Özet
Kortikal tabaka oluşumuyla sonuçlanan nöral migrasyon olarak adlandırılan süreç 3 . ve 6 . aylar arasında olmakla birlikte bu sürecin sağlıklı bir şekilde ilerleyememesi durumunda nöral migrasyon defekti oluşur. Ultrasonografi ve Manyetik rezonans görüntüleme ile bu durumun ve ek anomalilerin tespiti her geçen gün artmaktadır. Ultrasonografi ve Manyetik rezonans görüntüleme günümüzde fetusa ait bir çok anomali hakkında bilgi verebilirken, özellikle belirli haftalarda uygulandığında fetal beyin anomalilerini göstermede çok faydalıdır. Bu bildiride, literatür eşliğinde gebelikte fetal beyin yapılarının görüntüleme yöntemleri ile nöral migrasyon defekti bulguları tartışıldı.
\end{abstract}

Anahtar Kelimeler: Nöral migrasyon defekti, gebelik, görüntüleme.

Atıgan A, Kaleli MB, Nöral migrasyon defekti. Pam Tıp Derg 2019;12:165-166.

\begin{abstract}
The process called neural migration, which results in the formation of a cortical layer, occurs between the 3rd and 6th months, and if this process can not proceed in a healthy way, a neural migration defect occurs. With ultrasonography and magnetic resonance imaging, the detection of this condition and additional anomalies is increasing day by day. Ultrasonography and Magnetic Resonance Imaging can give information about many anomalies of the fetus nowadays. It is very useful in showing fetal brain anomalies especially when applied in major weeks. In this report, imaging methods of fetal brain structures and neural migration defect findings were discussed with the knowledge of in the literature.
\end{abstract}

Anahtar Kelimeler: Neural migration defect, pregnancy, imaging.

Atıgan A, Kaleli MB, Neural migration defect. Pam Med J 2019;12:165-166.

\section{Giriş}

Kortikal tabaka oluşumuyla sonuçlanan nöral migrasyon insanlarda başlıca gestasyonun 12 . ve 24. haftaları arasında meydana gelir [1]. Nöral migrasyon bozukluklarının sınıflandırılması şizensefali, porensefali, lisensefali, arjiri, makrogri, pakigiri, mikrogri ve mikropoligiri olmak üzere morfolojik kriterlere dayanır [2]. Santral sinir sisteminin malformasyonlarının patogenezi hem genetik hem de çevresel faktörleri içerir. Bu bildirinin amacı, nöral migrasyon defekti (NMD) olgusunu sunarak, NMD'nde karşılaştığımız radyolojik bulguları ve eşlik eden ek anomalileri güncel literatür eşliğinde tartışmaktır.

\section{Olgu Sunumu}

28 yaşında Gravida (4), Parite (2), Yaşayan çocuğu (2), Abortus (1) olan hasta, 22. haftada kontrol amacıyla başvurdu. Yapılan ultrasonografisinde (USG) sağ paryetel lobta parankimal kalınlık artışı gözlendi (Poliklinik muayenesi sırasında yapılan USG çıktısı alınmadığı için ekte sunulamamıştır). Yapılan fetal Manyetik Rezonans Görüntüleme (MRG) ile değerlendirmesinde sağ frontal ve paryetal lobta heterotopi ile uyumlu kortikal giral formasyonda düzleşme ve parankimal kalınlık artışı izlendi (Resim 1). Ayrıca periventriküler heterotopi ile uyumlu ventriküler duvarda ondülasyon izlendi (Resim 1). Ailenin tıbbi terminasyonu kabul

Ayhan Atıgan, Arş.Gör.Dr. Pamukkale Üniversitesi Tıp Fakültesi, Kadın Hastalıkları ve Doğum, DENIZLI, e-posta:dratigan@hotmail.com (orcid. org/0000-0002-7257-0593) (Sorumlu yazar)

Mehmet Babür Kaleli, Prof.Dr. Pamukkale Üniversitesi Tıp Fakültesi, Kadın Hastalıkları ve Doğum, DENıZLI, e-posta:tus20tus@hotmail.com (orcid. org/0000-0002-5122-9329) 
etmesi üzerine gebelik sonlandırılmasına gidildi. Ancak aile gebeliğin tahliyesinden sonra otopsi yapılmasını kabul etmediğinden otopsi raporu sunulamamıştır.

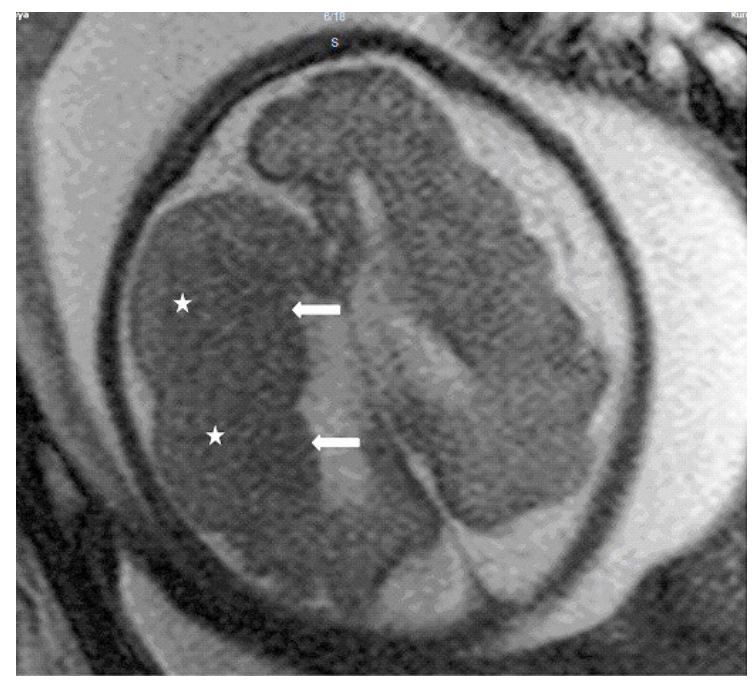

Resim 1. Nöral migrasyon defekti MR görüntüsü

\section{Tartışma}

Ultrasonografisinin major konjenital malformasyonları saptamadaki duyarlıı̆ı \%3050 , özgünlüğü ise $\% 90$ civarındadır. Serebral yapısal anomalilerve destrüktiflezyonlar prenatal sonografi ile netlikle ayırt edilememekte ancak fetal MRG ile tanısı konulabilmektedir. Beyin parankimi,serebral hemisfer çizgisi, posterior fossa ve periserebral sıvı alanlarının analizinde serebral MRG'ın, USG'den daha etkili olduğu gösterilmiştir [3]. Ayrıca fetal MRG beynin her iki hemisferinin netlikle görüntülenebilmesine olanak sağlar ve ultrasonografiye bu yönüyle de üstünlük göstermektedir [4]. Pediyatrik populasyonda beyin görüntülemede MRG'ın kullanımına bağı olarak nöronal migrasyon bozukluklarının insidansı net olarak bilinmemesine rağmen artmaktadır [5]. Yüksek su, düşük protein içeren fetal beyin dokusunda özellikle T2 ağırıklı MRG çok avantajlıdır. T1 ağırlıklı görüntüleme intraserebral hemoraji, yağ ve miyelinizasyon ilerlemesini değerlendirmek için kullanışlı olabilir. Fetal görüntülemede MRG için gestasyonel 28. ve 32. haftalar arası en uygun kullanım zamanıdır. Miyelin öncelikle gebeliğin 20. haftasında dorsal beyin sapında (duyusal yollar), 33. haftasında internal kapsülün posterior kanatlarında, 35. haftasında da subkortikal perirolandik beyaz cevher ve optik traktusta görülmektedir [6]. Levine ve Barnes fetal MRG'ı kullanarak kortikal olgunlaşmayı açıkça göstermişlerdir [7].

20. gebelik haftalarında her gebeye yapılması planlanan detaylı obstetrik USG inceleme ile diğer anomaliler gibi fetal kranial anomalilerde erken tanıya varılabilir. MRG, fetal kraniyal anomalilerde tarama amaçlı kullanılan ultrasonografiyi tamamlayan ve ek anomalileri ortaya koyan, özellikle migrasyon bozukluklarının değerlendirilmesinde kullanımı gittikçe yaygınlaşan, USG'deki öngörümüzü bir ileri aşamaya taşıyan veya kanıtlayan oldukça değerli bir inceleme yöntemidir. Gebeliğin 2 . trimester bitiminden önce USG ile topluma ulaşmaya çabalayabilir, şüpheli vakalarda tanıya varmak için USG sonrasında bir üst basamak olarak MRG kullanılabilir.Ayrıca, MRG ile bir çok kesit alınabildiğinden ve geriye dönük incelemesi kolay olduğundan diğer meslektaşlarımızın fikrini almak kolaylaşır. Obstetrisyen ve radyolog iş birliğinin artması sağlanabilir. Prenatal tanı, özellikle nörolojik sekelin beklendiği beyin anomalilerinde daha da önem kazanmakta ve gelişen teknolojinin kullanılması prenatal tanıda yeni ufuklar açmaktadır.

Çıkar İlişkisi: Yazarlar çıkar ilişkisi olmadığını beyan eder.

\section{Kaynaklar}

1. Gressens P. Mechanisms and disturbances of neuronal migration. Pediatr Res 2000;48:725-730.

2. Barth PG. Disorders of neuronal migration. Can J Neurol Sci 1987;14:1-16.

3. Denis D, Maugey LB, Carles D, Pedespan JM, Brun M, Chateil JF. Prenatal diagnosis of schizencephaly by fetal magnetic resonance imaging. Fetal Diagn Ther 2001;16:354-359.

4. Glenn OA, Barkovich AJ. Magnetic resonance imaging of the fetal brain and spine: an increasingly important tool in prenatal diagnosis. Part I. AJNR 2006;27:16041611.

5. Colombo N, Salamon N, Raybaud C, Ozkara C, Barkovich AJ. Imaging of malformations of cortical development. Epileptic Disord 2009; 11:194-205.

6. Girard N, Raybaud C, Gambarelli D, Figarella BD. Fetal brain MR imaging. MRI Clin N Am 2001;9:19-56.

7. Levine D, Barnes PD. Cortical maturation in normal and abnormal fetuses as assessed with prenatal MR imaging. Radiology 1999;210:751-758. 